\title{
Serological survey of porcine circovirus 2 antibodies in Northeastern Brazil by immunoperoxidase monolayer assay
}

\section{Investigação sorológica de circovirus suíno 2 em granjas comerciais de suínos da região Nordeste do Brasil pela técnica de imunoperoxidase em monocamada de células}

\author{
Priscila Rocha Duque ${ }^{1}$; Antonio Samuel Alves da Silva ${ }^{2}$; Marconi Rego Barros \\ Júnior $^{3}$; Andreza Maria Tenório Sergio ${ }^{4}$; Clara Nilce Barbosa ${ }^{5 *}$
}

\begin{abstract}
Porcine circovirus 2 (PCV2) specific antibodies were evaluated in pigs at 15 to 25 weeks of age by immunoperoxidase monolayer assay. Serum samples $(n=575)$ were obtained from 16 commercial farms located in six states of northeastern Brazil, including two in Ceará $(n=85)$, three in Rio Grande do Norte $(n=92)$, two in Paraíba $(n=49)$, three in Pernambuco $(n=107)$, two in Alagoas $(n=39)$, and four in Bahia $(n=203)$. Out of the 575 evaluated sera, $470(81.74 \%)$ were reagents with antibody titers ranging from 20 to 5,120 . All farms presented reactive animals. There was a statistically significant difference in reactivity proportions between the states of Bahia and Ceará $(p<0.05)$ and between Bahia and Rio Grande do Norte $(p<0.05)$. This study provides the first serological investigation for PCV2 in pigs from commercial farms in Northeastern Brazil.
\end{abstract}

Key words: Circoviridae. Infection. Serum. Pig. Virus.

\section{Resumo}

A presença de anticorpos específicos contra o circovirus suíno 2 (PCV2) foi avaliada em suínos com 15 a 25 semanas de idade pela técnica de imunoperoxidase em monocamada de células. As amostras de soros $(n=575)$ foram procedentes de 16 granjas comerciais localizadas em seis Estados da região Nordeste do Brasil, incluindo duas no Ceará $(n=85)$, três no Rio Grande do Norte $(n=92)$, duas na Paraíba $(n=49)$, três em Pernambuco $(n=107)$, duas em Alagoas $(n=39)$ e quatro na Bahia $(n=203)$. Dos 575 soros avaliados, $470(81,74 \%)$ foram reagentes com títulos de anticorpos que variaram de 20 até 5.120. Todas as granjas avaliadas apresentaram animais reagentes. Houve diferença estatística significante nas proporções de sororeatividade entre os Estados da Bahia e Ceará $(p<0,05)$ e entre os Estados Bahia e Rio Grande do Norte $(p<0,05)$. Este estudo mostra a primeira investigação sorológica para PCV2 em suínos de granjas comerciais da região Nordeste do Brasil.

Palavras-chave: Circoviridae. Infecção. Soro. Suíno. Vírus.

1 Pós-Graduanda, Residência Multiprofissional de Vigilância em Saúde, Secretaria de Saúde do Recife, Recife, PE, Brasil. priscilard.ufrpe@gmail.com

2 Prof., Departamento de Estatística e Informática, Programa de Pós-Graduação em Biometria e Estatística Aplicada, Universidade Federal Rural de Pernambuco, UFRPE, Recife, PE, Brasil. E-mail: samuelmatematico@yahoo.com.br

3 Prof., Núcleo de Pesquisa em Ciências Biomédicas, Faculdade Sete de Setembro, FASETE, Paulo Afonso, BA, Brasil. E-mail: marconijrr@gmail.com

4 Discente, Programa de Pós-Graduação em Medicina Veterinária, UFRPE, Recife, PE, Brasil. E-mail: andreza.tenorioo@gmail.com

5 Profa., Departamento de Medicina Veterinária, Programa de Pós-Graduação em Medicina Veterinária, UFRPE, Recife, PE, Brasil. E-mail: claranbarbosa@yahoo.com

Author for correspondence 
More than two decades after its discovery, porcine circovirus 2 (PCV2) remains an economically important pathogen for the pig industry (Allan et al., 1998). The virus belongs to the Circoviridae family, has a single-stranded covalently closed circular DNA, and exhibits a non-enveloped icosahedral structure (Tischer, Gelderblom, Vettermann, \& Koch, 1982). Infection can result in a variety of clinical manifestations called PCVAD-porcine circovirus 2 associated diseases. Among the PCVAD, the postweaning multisystemic wasting syndrome (PMWS) is responsible for a high economic impact on world pig production (Allan et al., 1998; Opriessnig, Meng, \& Halbur, 2007; Alarcon, Rushton, \& Wieland, 2013). Serological research has shown a wide distribution of PCV2 in the world pig population (Magar, Muller, \& Larochelle, 2000; Mesu, Labarque, Nauwynck, \& Pensaert, 2000; Zhou et al., 2006). In Brazil, after the identification of PCV2 by Zanella, Morés, Schiochet and Trombetta (2001), viral reactivity has been demonstrated in the South and Southeast regions (Barbosa, Lobato, Martins, \& Nascimento, 2008), but information about PCV2 is scarce in the Northeast region, and epidemiological studies are essential to promote prevention and control programs with emphasis on swine health. Several serological techniques are available for PCV2 antibody detection (Magar et al., 2000; Opriessnig et al., 2007), including immunoperoxidase monolayer assay (IPMA) (Rodriguez-Arrioja et al., 2000). This study aimed to evaluate the presence of antibodies against PCV2 by IPMA in pigs from commercial farms in Northeastern Brazil.

A total of 575 blood samples were collected from crossbreed pigs (landrace and large white) of both sexes during the bleeding procedure at the slaughterhouse. Pigs came from 16 commercial farms located in six states of the Northeast region of Brazil, including two in Ceará (CE), three in Rio Grande do Norte ( $R N)$, two in Paraíba, three in Pernambuco (PE), two in Alagoas (AL), and four in Bahia (BA). The criteria used for including the animals in the study were as follows: the farm should have at least 40 breeders and no history of vaccination against PCV2 and animals aged 15 to 25 weeks and clinically healthy based on antemortem inspection. This research was authorized by CEUA no. 006/2015 and 097/2016 of the Federal Rural University of Pernambuco (UFRPE).

The serological evaluation was performed using the IPMA technique, as described by RodriguezArrioja et al. (2000). Serum samples were diluted from 1:20 to 1:5120 in 96-well plates containing porcine kidney cells (SK6, swine kidney 6) previously infected with PCV2 (origin: University of Minnesota, USA). To interpret the results, positive sera were classified as reactive and negative sera as nonreactive. According to the categorization of Rodriguez-Arrioja et al. (2000), the reactive sera were grouped into low (20 to 160), medium (320 to 2560), and high titers (equal to or greater than $5120)$.

Serological surveys conducted from 1989 to 2011 on the European, Asian, and American continents have shown PCV2 seroreactivity ranging from 25 to $98 \%$ in finishing pigs (Mesu et al., 2000; Rodriguez-Arrioja et al., 2000; Zhou et al., 2006; Barbosa, Martins, Esteves, \& Freitas, 2011). A total of $470(81.74 \%)$ out of the 575 evaluated sera were reactive, being 190 (40.43\%) low, 265 (56.38\%) medium, and 15 (3.19\%) high. All farms presented reactive animals. The antibodies found are specific against PCV2 since the IPMA test used SK6 cell monolayer previously infected with PCV2, and the analyzed sera came from pigs with no history of vaccination against PCV2.

Our results showed a high relative frequency (RF) $(81.74 \%)$ of seroreactive animals and farms (100\%). Similar results were found by Mesu et al. (2000) in Belgium and Barbosa et al. (2008) in the South and Southeast of Brazil. In both studies, the authors detected antibodies to PCV2 in $100 \%$ of the analyzed commercial herds. Subsequent studies carried out by Barbosa (2011) in commercial farms 
with and without clinical signs of PMWS in the State of Minas Gerais, showed a $96.6 \%$ seroreactivity. However, our results revealed a lower seroreactivity percentage (81.74\%), but sampling was lower (470), and animals were clinically healthy.

In Northeastern Brazil, there are few studies on PCV2, but Pontes, Barbosa, Jesus, Silva and Freitas (2012) identified, in Pernambuco, the presence of PCV2 by the polymerase chain reaction (PCR) technique in $100 \%(55 / 55)$ of biological samples (lung and mediastinal lymph node) from finishing pigs. The high viral seroreactivity observed in the sampled region may be associated with the introduction of PCV2-infected animals in the herd. It is supported by Kim, Han, Choiia and Chae (2003) and Rose, Opriessnig, Grasland and Jestin (2012), who found that among herds viral transmission is restricted to the introduction of asymptomatic animals and use of biological materials such as semen infected by PCV2. According to reports from swine producers in the Northeast region, purchases of replacement breeders come from commercial farms located in the South and Southeast of Brazil, which are the most economically important regions in the industrial production of pigs. Although the replacement breeders of the herd came from certified swine farms, the current legislation (SDA Normative No. 19 of February 15, 2002, published in DOU No. 41, Section 1, of 03/01/2002) does not require animals to be $\mathrm{PCV} 2$ free.

The analyses showed that Ceará $(90.59 \%, 8 / 77)$ and Rio Grande do Norte $(88.04 \%, 11 / 81)$ had the highest RF, followed by Alagoas $(87.18 \%, 5 / 34)$ and Paraíba $(85.71 \%, 7 / 42)$. In contrast, Pernambuco $(80.38 \%, 21 / 86)$ and Bahia $(73.39 \%, 53 / 150)$ had the lowest RF, as shown in Table 1. The binomial test (Sampaio, 2002) at a 5\% significance level showed that the proportions of seroreactivity in the states of Bahia and Ceará, as well as the proportions of seroreactive in Bahia and Rio Grande do Norte, present significant differences, as indicated by different letters in Table 1 and Figure 1. As selection criteria, the farms included in the study follow the industrial system model and adopt the production scale. One of the possibilities that may have contributed to variations in seroreactivity between farms and significant differences $(p<0.05)$ between states is the production management quality and failures in hygiene programs. The literature has shown that epidemiological characteristics of the pathogen associated with the modern swine production system guarantee a continuous exposure of animals to the virus. According to C. N. Barbosa et al. (2008), PCV2 circulates at all stages of the production cycle. Rose et al. (2012) described that the virus could be maintained within herds for years due to population dynamics in modern swine production systems. The horizontal transmission is the most common and occurs mainly by direct contact between animals. Also, virus can be excreted via different routes, remaining in the herd due to environmental stability (Tischer et al., 1982; Opriessnig et al., 2017).

Previous exposure of animals to the virus occurred during the production cycle, and detected antibodies are a response of viral infection. Moreover, antibody titers ranged from 20 to 160 (low) to $\geq 5120$ (high). Thus, seroreactive animals may be acting as possible sources of viral infection until the final stage of the production cycle, regardless of the clinical development of the disease. The virus can be spread within the herd due to the presence of asymptomatic animals and subclinical infections (Barbosa et al., 2011; Rose et al., 2012). Mesu et al. (2000) reported that PCV2 infections occur systematically in pigs, and other factors, such as management, housing, and/or concomitant bacterial and viral infections, are probably necessary to induce the onset of the syndrome in the herd. Considering that all analyzed commercial farms showed seroreactive animals and adopted the industrial production system, the animals may be susceptible to the development of PCVAD. 
Table 1. Distribution of frequencies of serological reactivity for porcine circovirus 2 (PCV2) in pigs from commercial farms in Northeastern Brazil.

\begin{tabular}{lcccc}
\hline State & $\begin{array}{c}\text { Number of analyzed } \\
\text { farms }\end{array}$ & $\begin{array}{c}\text { Number of analyzed } \\
\text { sera }\end{array}$ & $\begin{array}{c}\text { Number of reactive sera } \\
(\%)\left(\mathrm{AF}^{*} / \mathrm{RF}^{* *}\right)\end{array}$ & $\begin{array}{c}\text { Number of nonreactive } \\
\text { sera }\left(\mathrm{AF}^{*} / \mathrm{RF}^{* *}\right)\end{array}$ \\
\hline $\mathrm{AL}$ & 2 & 39 & $34(87.18 \%) \Delta \mathrm{ab}$ & $5(12.82 \%)$ \\
$\mathrm{BA}$ & 4 & 203 & $150(73.89 \%) \mathrm{a}$ & $53(18.26 \%)$ \\
$\mathrm{CE}$ & 2 & 85 & $77(90.59 \%) \mathrm{b}$ & $8(9.41 \%)$ \\
$\mathrm{PB}$ & 2 & 49 & $42(85.71 \%) \mathrm{ab}$ & $7(14.29 \%)$ \\
$\mathrm{PE}$ & 3 & 107 & $86(80.38 \%) \mathrm{ab}$ & $21(19.63 \%)$ \\
$\mathrm{RN}$ & 3 & 92 & $81(88.04 \%) \mathrm{b}$ & $11(11.96 \%)$ \\
\hline TOTAL & 16 & 575 & $470(81.74 \%)$ & $10518.26 \%)$ \\
\hline
\end{tabular}

AL: Alagoas, BA: Bahia, CE: Ceará, PB: Paraíba, PE: Pernambuco, RN: Rio Grande do Norte.

*Absolute frequency, $* *$ Relative frequency.

$\Delta$ Different letters in the rows represent significant differences between proportions of reactive animals $(p<0.05)$.

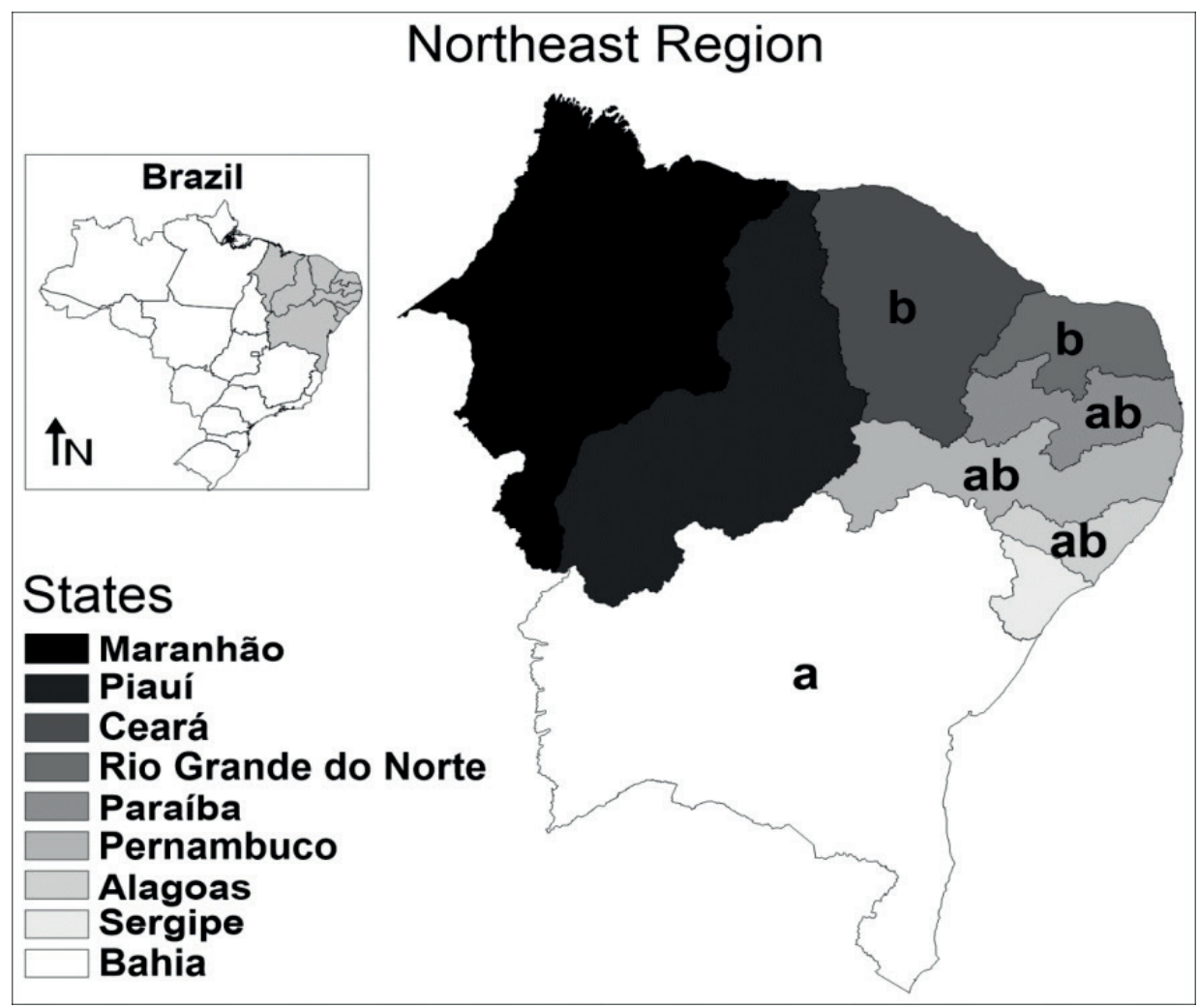

Figure 1. Geographical location of the Northeast region. States with different letters show significant differences between the proportions of reactive animals.

In conclusion, this study showed the presence of specific antibodies against PCV2 by the IPMA technique in commercial swine farms in Northeastern
Brazil and the obtained information points to the implementation of biosecurity measures. 


\section{References}

Alarcon, P., Rushton, J., Wieland, B. (2013). Cost of post-weaning multi-systemic wasting syndrome and porcine circovirus type 2 subclinical infection in England-An economic disease model. Preventive Veterinary Medicine, 110(2), 88-102. doi: 10.1016/j. prevetmed.2013.02.010

Allan, G. M., Mcneilly, F., Kennedy, S., Daft, B., Clarke, E. G., Ellis, J. A.,... Adair, B. M. (1998). Isolation of porcine circovirus-like viruses from pigs with a wasting disease in the USA and Europe. Journal of Veterinary Diagnostic Investigation, 10(1), 3-10. doi: 10.1177/104063879801000102

Barbosa, C. N., Lobato, Z. I. P., Martins, N. R. S., Nascimento, E. F. (2008). Perfil sorológico para circovírus suíno tipo 2 em granjas comerciais de suínos no Brasil. Arquivo Brasileiro de Medicina Veterinária e Zootecnia, 60(4), 815-820. doi: 10.1590/s0102-09352008000400006

Barbosa, C. N., Martins, N. R. S., Esteves, E. G., Freitas, T. R. P. (2011). Pesquisa de antígenos e anticorpos contra Circovírus Suíno II em suínos com e sem sintomatologia da síndrome multisistêmica do definhamento em granjas comerciais mineiras. Semina: Ciências Agrárias, 32(4), 1513-1526. doi: 10.5433/1679-0359

Kim, J., Han, D. U., Choii, C., Chae, C. (2003). Simultaneous detection and differentiation between porcine circovirus and porcine parvovirus in boar semen by multiplex seminested polymerase chain reaction. Journal of Veterinary Medical Science, 65(6), 741-744. doi: 10.1292/jvms.65.741

Magar, R., Muller, P., Larochelle, R. (2000). Retrospective serological survey of antibodies to porcine circovirus type 1 and type 2. The Canadian Journal of Veterinary Research, 64(3), 184-186. PMCID: PMC1189611

Mesu, A. P., Labarque, G. G., Nauwynck, H. J., Pensaert, M. B. (2000). Seroprevalence of porcine circovirus types 1 and 2 in the Belgian pig population. The Veterinary Quarterly, 22(4), 234-236. doi: $10.1080 / 01652176.2000 .9695065$

Opriessnig, T., Meng, X. J., Halbur, P. G. (2007). Porcine circovirus type 2 associated disease: update on current terminology, clinical manifestations, pathogenesis, diagnosis, and intervention strategies. Journal of Veterinary Diagnostic Investigation, 19(6), 591-615. doi: 10.1177/104063870701900601
Opriessnig, T., Xiao, C. T., Halbur, P. G., Gerber, P. F., Matzinger, S. R., Meng, X. J. A. (2017). commercial porcine circovirus (PCV) type 2a-based vaccine reduces $\mathrm{PCV} 2 \mathrm{~d}$ viremia and shedding and prevents PCV2d transmission to naïve pigs under experimental conditions. Vaccine, 35(2), 248-254. doi: 10.1016/j. vaccine.2016.11.085

Pontes, N. E., Barbosa, C. N., Jesus, A. L. S., Silva, J. G., Freitas, A. C. (2012). Development and Evaluation of single-tube nested PCR (STNPCR) for the detection of porcine circovirus type 2 (PCV2). Transboundary and Emerging Diseases, 61(3), 233238. doi: $10.1111 /$ tbed.12022

Rodriguez-Arrioja, G. M., Segalés, J., Balasch, M., Rosell, C. J., Quintana, J., Folch, J. M., Domingo, M. (2000). Serum antibodies to porcine circovirus type 1 and type 2 in pigs with and without PMWS. Veterinary Record, 146(26), 762-764. doi: 10.1136/ vr.146.26.762

Rose, N., Opriessnig, T., Grasland, B., Jestin, A. (2012). Epidemiology and transmission of porcine circovirus type 2 (PCV2). Virus Research, 164(1-2), 78-89. doi: 10.1016/j.virusres.2011.12.002

Sampaio, I. B. M. (2002). Estatística aplicada à experimentação animal. Belo Horizonte: Fundação de Estudo e Pesquisa em Medicina Veterinária e Zootécnica.

Tischer, I., Gelderblom, H., Vettermann, W., Koch, M. A. (1982). A very small porcine virus with circular single-stranded DNA. Nature, 295(5844), 64-65. doi: $10.1038 / 295064 \mathrm{a} 0$

Zanella, J. R. C., Morés, N., Schiochet, M. F., Trombetta, C. (2001). Diagnóstico molecular e caracterização de circovírus suíno tipo 2 isolados no Brasil. Anais do Congresso Brasileiro de Veterinários Especialistas em Suínos, Porto Alegre, RS, Brasil, 11.

Zhou, J. Y., Chen, Q. X., Ye, J. X., Shen, H. G., Chen, T. F., Shang, S. B. (2006). Serological investigation and genomic characterization of PCV2 isolates from different geographic Regions of Zhejiang Province in China. Veterinary Research Communications, 30(2), 205-20. doi: 10.1007/s11259-006-3203-x 
